\title{
sciendo

\section{Sprayed Water Flowrate, Temperature and Drop Size Effects on Small Capacity Flue Gas Condenser's Performance}

\author{
Vivita PRIEDNIECE ${ }^{1 *}$, Elvis KALNINS ${ }^{2}$, Vladimirs KIRSANOVS ${ }^{3}$, Mikelis DZIKEVICS $^{4}$, \\ Dagnija BLUMBERGA ${ }^{5}$, Ivars VEIDENBERGS ${ }^{6}$
}

\author{
${ }^{1-6}$ Institute of Energy Systems and Environment, Riga Technical University, Azenes iela 12/1, \\ Riga, LV-1048, Latvia
}

\begin{abstract}
One of the main pollution types is air pollution, which has a significant impact on the surrounding environment and on living beings. Major source of air pollution is combustion processes. There are many flue gas treatment technologies around the world. In this paper a new, innovative flue gas treatment technology - fog unit - is introduced. The goal of the fog unit is to treat flue gases that are emitted from households. In the European Union, including Latvia, at the beginning of 2020, a directive will come into effect that will set limits for emissions and the effectiveness for incinerators in households. The main focus of this study was to determine the most optimal operating mode for the fog unit by changing different operating parameters: sprayed water temperature, sprayed water flowrate and types of nozzles (drop diameters). Results show that the most optimal operating mode in terms of flue gas treatment efficiency and recovered energy is at water temperature: $20^{\circ} \mathrm{C}$, sprayed water flowrate: $250 \mathrm{l} / \mathrm{h}$ and nozzle: MPL1.12 M. However, electrical consumption of water circulation pump leaves negative effect on this operating mode.
\end{abstract}

Keywords - Drop diameters; flue gas treatment; fog unit; nozzle size; sprayed water flowrate; water temperature

\section{Introduction}

The environment is contaminated every day by different pollutants, and one of the main types is air pollution. Long-term exposure to contaminated air can lead to serious health problems, for example, it can affect the respiratory, nervous and cardiovascular systems [1]. Besides possible health problems, air pollution can also significantly affect the environment. During the combustion processes so-called greenhouse gases (carbon dioxide, nitrogen oxides, carbon monoxide and others) are emitted [2]. From combustion processes, particulate matter (PM) is also emitted.

Particulate matter is a term used to describe a mixture of dust like particles and small liquid drops. They can be divided in natural and human made particulate matter. PM can also be divided by size into: coarse $(2.5-10 \mu \mathrm{m})$, fine $(<2.5 \mu \mathrm{m})$ and dust-like $(<0.1 \mu \mathrm{m})$ particles. Studies have proved, that particulate matter, especially, from combustion processes are a cause for different inflammation, as well as cardiovascular and respiratory diseases.

\footnotetext{
* Corresponding author.

E-mail address: vivita.priedniece@rtu.lv
}

C2019 Vivita Priedniece, Elvis Kalnins, Vladimirs Kirsanovs, Mikelis Dzikevics, Dagnija Blumberga, Ivars Veidenbergs. This is an open access article licensed under the Creative Commons Attribution License (http://creativecommons.org/ licenses/by/4.0), in the manner agreed with Sciendo. 
People breathe in different particulate matter that at first travels to the bronchial system and later can even transfer to the bloodstream. The growing tendency of respiratory, heart and vascular diseases in the population which has been in contact with PM for a long time, supports the possible harms caused by PM. The growth of PM from 10 to $20 \mu \mathrm{g} / \mathrm{m}^{3}$ increases the mortality rate from cardiovascular diseases by 0.5 to $2 \%$ [3], [4].

Particulate matter pollution in Latvia from stationary sources fluctuates over time. Statistical data is available from 2009 to 2016. The lowest PM emissions were reached in 2011 and it was 2690 tonnes, followed by 2016 and 2727 tonnes. The highest PM emissions were recorded in 2015 at 3559 tonnes, with emissions from other years $(2009,2010,2012$ 2014) all being above 3000 tonnes. PM pollution is one of the main pollution types in Latvia, the main sources of which are: transport, combustion equipment, industrial processes and cross-border transfer. It has to be noted that a significant, but poorly studied PM source is the household sector, which uses biomass as fuel for energy production [5].

PM concentration limits are set globally and locally. At the global level they have been set by the World Health Organization. The average annual $\mathrm{PM}_{2.5}$ emissions should not exceed $10 \mu \mathrm{g} / \mathrm{m}^{3}$, but $\mathrm{PM}_{10}$ emissions should not exceed $20 \mu \mathrm{g} / \mathrm{m}^{3}$. Average twenty-four-hour emission limit for $\mathrm{PM}_{2.5}$ is $25 \mu \mathrm{g} / \mathrm{m}^{3}$, but for $\mathrm{PM}_{10}$ it is $50 \mu \mathrm{g} / \mathrm{m}^{3}$. PM emission limits in Latvia are $50 \mu \mathrm{g} / \mathrm{m}^{3}$ for $\mathrm{PM}_{10}$ for twenty-four hours, that can be exceeded 35 times in a calendar year and $40 \mu \mathrm{g} / \mathrm{m}^{3}$ annually. Emission limits for $\mathbf{P M}_{2.5}$ are frequently calculated, with a set goal value of $20 \mu \mathrm{g} / \mathrm{m}^{3}$ annually by year 2020. The recommended PM limits for protection of human health for $\mathrm{PM}_{2.5}$ are between 12 and $17 \mu \mathrm{g} / \mathrm{m}^{3}$ [6], [7]. $\mathrm{PM}_{10}$ emissions are frequently measured and monitored in four cities in Latvia. Their annual average values for 2016 is $80 \mu \mathrm{g} / \mathrm{m}^{3}$ in Riga, $84.6 \mu \mathrm{g} / \mathrm{m}^{3}$ in Liepaja, $21.7 \mu \mathrm{g} / \mathrm{m}^{3}$ in Rezekne and $78.1 \mu \mathrm{g} / \mathrm{m}^{3}$ in Ventspils. Three of the mentioned emission values exceed the annual limits set both globally and at the country level, which is not a good sign for environment and human health, leading to increased risk of disease [5], [8]. Therefore, PM emissions have to be decreased and considered as a significant threat.

There were two main energy resources used in Latvian households for the production of heat during the period of 1996-2015: fire wood and natural gas. As the years passed, the consumption of firewood in Latvian households, including agricultural holdings and other economic activities, has fallen from $83.61 \%$ in 1996 to $69.9 \%$ in 2015 . However, wood pellet consumption has grown from $0.11 \%$ in 2006 to $8.77 \%$ in 2015 (data is not available for 1996 and 2001) [9]. The unmistakable dominance of firewood in energy consumption in Latvian households, including consumption in agricultural holdings and other economic activities, could be explained by its relatively low cost, widespread availability, as well as the excluded need to purchase special incinerators. Further increase of biomass use for heat production is expected, as fossil fuel sources are depleting, leading to increase in their prices. Also, the European Union is demanding transfer to renewable energy sources and developing policies to decrease and eliminate $\mathrm{CO}_{2}$ emissions.

Statistics show that in 2013 in 28 countries of the EU approximately $58 \%$ of population lived in households that mostly use boilers for heat production, where biomass is the main fuel. The largest emission producers at households are fireplaces and stoves, that are fired with firewood, wood logs or forestry leftovers - leaves, twigs. Deposits in case of biomass combustion are soot and char. Analysis of these deposits can be used to study the quality of combustion processes and combustion equipment [10].

Biomass is a fuel of varying quality, with lower carbon content, higher oxygen and volatile content and lower heating value and energy density than fossil fuels, such as coal. Biomass can also contain elements like nitrogen, chlorine, sulfur, phosphorus and different metals. 
These contents create different challenges for use (corrosion, fouling, etc.). The choice of certain combustion equipment is dependent on fuel to be used. Differences in fuel composition have to be taken into account during design of equipment and during operation [11], [12].

Biomass use in boilers leads to ash-related problems, reducing heat transfer in the systems, therefore reducing efficiency and capacity of the boiler. Ash deposition is a complex process, that cannot be fully described by traditionally used methods (fusibility, viscosity, slagging and fouling indices) [13].

Nitrogen oxides are harmful pollutants from solid fuel combustion that promotes photochemical smog, tropospheric ozone, greenhouse effect and acid rains formation. In the study of Besenic et al. a numerical model for predicting nitrogen oxide emissions from solid fuel (pulverized biomass and coal) combustion was made. The model has high accuracy and it can be used for detailed studies of combustion systems and pollution trend predictions [14].

Although wood and its products have a significant role as fuel globally to control climate change, it has disadvantages related to particulate matter emissions. A study conducted in Bavaria state in Germany has proved that its greenhouse gas emissions would increase by approximately $13 \%$ without the use of wood fuels, however PM emissions would decrease by $77 \%$. Also combustion of wood creates emissions of particulate black carbon (IPCC) which is the second most important agent of global warming. Therefore, improvements of wood combustion systems and flue gas treatment technologies is an important topic [15]. European emission inventory data for 2017 shows that residential combustion equipment is responsible for $52 \%$ of $\mathrm{PM}_{2.5}$ emissions, $53 \%$ of polycyclic aromatic hydrocarbon and $72 \%$ of benzopyrene emissions [16].

It is also important to consider bioclimatic architectural design principles to improve energy efficiency and thermal comfort of buildings, especially households, that could lead to enhancements in indoor air quality [17]. Another topic to consider is alternative combustion technologies, like small scale biomass gasification. Biomass gasification is a comparatively simple technology without high investment costs that uses widely available fuel. However, small-scale gasifiers are meant for decentralized use at small-scale companies, not households. [18].

Development of new flue gas treatment technologies and increasing use of them is additionally promoted by the Eco-design directive. It determines that emissions from combustors in households cannot exceed limits set by the European Union. Also energy efficiency limits will be set for all of the incinerators used in households. The eco-design directive will set few rules for households:

- For boilers with automatic fuel supply, the emissions of particles during the heating season shall not exceed $40 \mathrm{mg} / \mathrm{m}^{3}$ and for boilers with manual fuel supply $60 \mathrm{mg} / \mathrm{m}^{3}$;

- Seasonal space heating efficiency for boilers with a rated heat output of $20 \mathrm{~kW}$ or less shall not be less than $75 \%$;

- Seasonal space heating energy efficiency for boilers with a rated heat output exceeding $20 \mathrm{~kW}$ shall not be less than $77 \%$ [19].

Flue gas treatment (removal of particulate matter) from industrial combustion objects and boiler houses is a mandatory requirement regulated by national law. Therefore, many different technologies exist for PM emissions reduction - cyclone, spray tower, condenser, Venturi scrubber, electrostatic precipitator, fabric filters and others. All of these methods have advantages and disadvantages and can be used for flue gas treatment from a specific heat production source. 
There are many technologies available, but most of them are meant for use in the industrial sector. None of the previously mentioned flue gas treatment methods are suitable for household use, because of their required space, operational costs and necessary investments. At this moment, more frequently used technologies for PM emission treatment from small heat production sources are electrostatic precipitators and fabric filters. Electric charge, that removes PM from flue gas flow, is the basis of operation in electrostatic precipitators. Particles are affected by an electric charge that is created by electrodes built in the device walls. Precipitators are widely used as pollution monitoring systems, with high efficiency and thermal resistance. Fabric filters are a flue gas treatment technology with high efficiency, however, their use is limited to dry flue gases. The main advantage of this technology is, that there are no limits to particle size and, additionally, it can remove gaseous pollutants from flue gas [20]. The main disadvantage of precipitators is low resistance to chlorides that can be found in flue gases in various amounts. Other disadvantages of the aforementioned technologies are: high electricity consumption, increased flue gas resistance, necessity for additional equipment, frequent maintenance [20].

Condensers in use in industrial applications are indirect and direct contact economizers. The cooling matter in these devices is air or water. Indirect contact condensers are mostly used in real life applications, due to latent heat recovery. Direct contact condensers are with chambers for vapour conditioning and flue gas cooling [21].

A novel technology for flue gas treatment is nonporous organic membranes. In the study of Gao et al., hollow fibre composite PES-SPEEK (polyether sulfone-sulfonated polyether ether ketone) membranes are used to provide moisture removal and latent heat recovery from combustion flue gas. The performance of membranes is measured using moisture recovery efficiency, heat flux of recovered heat and permeability of the material [22].

Boilers that use condensers have a high corrosion risk, therefore corrosion-resistant materials like stainless steel, Teflon coatings or glass have to be used for the flue gas treatment equipment. Flue gas can create up to $20 \%$ of heat losses from boilers, but the use of condensers can help recover $50 \%$ from them, depending on operating conditions [23]. Significant processes to be provided by condenser are venting of non-condensable gases and condensate draining. Accumulation of these substances in the equipment can lead to faults in performance of equipment [24].

An innovative technology for particulate matter emissions treatment is presented in this study. It is called a fog unit - a flue gas condenser, that is meant for use after small capacity boilers in households and provides treatment of flue gas using the "fog effect" (small water drops $(d<1 \mathrm{~mm})$ ). An additional advantage of this technology is recovery of heat, which, in turn, increases overall efficiency of the boiler.

An increase in boiler efficiency leads to decrease in fuel consumption and emissions, possibly creating energy savings from heat. Additional measures to control heat losses have to be made. Together with the use of flue gas treatment technologies, boiler system can be significantly improved, increasing comfort of users [25].

There are a large number of factors affecting the efficiency of condenser technology for flue gas treatment. Literature review offers different relationships regarding parameters that affect flue gas treatment, for instance:

- By increasing sprayed water amount, treatment efficiency and heat energy performance can be increased [26];

- By reducing sprayed water temperature, deeper flue gas cooling can be achieved and more sensible heat can be recovered [27]. 
Size of sprayed water drops has a strong influence on heat and mass transfer processes inside the condenser and the amount of recovered heat in the end [28].

Results of the study done by Terhan et al. [29] show that primary energy savings of around $11 \%$ can be achieved by installing flue gas condenser. This value is reasonable, since many other researches also present typical energy source efficiency growth by $10-15 \%$ using condenser technology [30]. There is a critical temperature for flue gas cooling, after reaching which, it is not economically reasonable to further reduce the flue gas temperature and this effect promotes several technical problems. Research done by Wei et al. show that this critical point typically varies in a range from 28 to $32{ }^{\circ} \mathrm{C}$ [27].

In this case, it was decided, that performance of developed innovative technology will be examined depending on three variable parameters. This study presents results of experimental research where optimal parameters for operation of the fog unit were found. The energy efficiency of provided technology was selected as the main criteria in this case. However, in another study about the same technology, it will be possible to find results, where the main focus was put on particulate matter decrease possibilities using the fog unit [31].

\section{Methodology}

The experimental stand of the proposed flue gas treatment technology has been made in Combustion research laboratory in the Institute of Energy Systems and Environment. The experimental system consists of a pellet boiler, flue gas stack, fog unit and water hydraulic system.

Pellet boiler Grandeg-GD25 was selected for heat and flue gas production. This kind of boiler is widely used in households in Latvia. The boiler was operated at constant operation mode during all tests to determinate fog unit's operation effect on technology performance without affecting boiler performance. The same type of pellets was used in all tests, since used fuel has strong effect on the boiler energy efficiency and produced emission amounts. During the tests, wood pellets with lower heating value of $18.29 \mathrm{MJ} / \mathrm{kg}$, moisture content of $4.55 \%$ and ash content of $0.67 \%$ were used. The boiler was operated in constant mode during all tests. The main boiler operation parameters are:

- Capacity $20 \mathrm{~kW}$;

- Efficiency $86.8 \%$

- Flue gas temperature $121^{\circ} \mathrm{C}$;

- Flue gas relative humidity $3.2 \%$;

- Flue gas absolute humidity $26.1 \mathrm{~g} / \mathrm{kg}$;

- Particulate matter concentration in flue gas $36.2 \mathrm{mg} / \mathrm{Nm}^{3}$.

The fog unit consists of flue gas inlet and outlet, water supply system, nozzles for water spraying, pulp capture tank and separator. Flue gas is injected in the fog unit at the bottom part moving up, where flue gas outlet is located. Water is sprayed in the fog unit from the top using special nozzles. Sprayed water drop size is small and fog effect is made inside the condenser as a result.

Mass and heat transfer between flue gas and sprayed water promotes that particulate matter is caught by water drops and removed from flue gas. Water exits the fog unit from the bottom and moves to pulp capture tank. Sedimentation process is used to separate particulate matter from water. Particulate matter is accumulated at the bottom of pulp capture tank, but the water is recirculated back to the fog unit. At the same time, flue gas cooling occurs and injected water temperature increases as a result. A heat exchanger was installed at sprayed water 
circulation loop to provide constant injected water temperature. The heat removed from flue gas can be used for household heating and hot water preparation.

Monitoring system was developed to investigate the influence of different factors on fog unit's performance and to find optimal operation parameters. Monitoring system consists of:

- Heat meters for measuring capacities of the boiler and the fog unit;

- Weight platform to determine fuel consumption of the boiler;

- Hygrometers for measuring flue gas temperature, relative and absolute humidity before and after the fog unit;

- Anemometer to measure flue gas velocity;

- Differential pressure sensor to determine differential pressure before and after the fog unit;

- Flue gas analyser for flue gas chemical composition analysis before and after condenser;

- Particulate matter measurement unit for particulate matter concentration analysis before and after condenser;

- Heat meters for measuring fog unit's capacity and sprayed water flowrate;

- Manometer for measuring sprayed water pressure;

- Temperature sensors for sprayed water temperature determination before and after the fog unit.

The system and its operation are described in detail in the work of Priedniece et al. [32]. The analysis of first results obtained in experiments and their comparison with primary mathematical model are described in the follow up article of Priedniece et al. [33].

It this study, the performance of the fog unit was explored using various types of nozzles, sprayed water flowrates and sprayed water temperatures. Three water flowrates were used $50 \mathrm{l} / \mathrm{h}, 150 \mathrm{l} / \mathrm{h}$ and $250 \mathrm{l} / \mathrm{h}$ and three inlet water temperatures $-20{ }^{\circ} \mathrm{C}, 30^{\circ} \mathrm{C}$ and $40{ }^{\circ} \mathrm{C}$. Also, three full cone nozzles were used - MPL0.77 M, MPL1.12 M and MPL1.51 M. The water drops sizes vary depending on sprayed water flowrate. It was determined that drop size influences particulate matter treatment efficiency and flue gas temperature decrease. The operation parameters of the fog unit used in this research are presented in Table 1.

TABLE 1. FOG UNIT OPERATION PARAMETERS

\begin{tabular}{llcccccccc}
\hline Nozzle type & \multicolumn{3}{c}{ MPL0.77 M } & \multicolumn{3}{c}{ MPL1.12 M } & \multicolumn{3}{c}{ MPL1.51 M } \\
\hline Water flow, $1 / \mathrm{h}$ & 50 & 150 & 200 & 50 & 150 & 250 & 50 & 150 & 250 \\
Water pressure, bar & 0.4 & 1.9 & 3.4 & 0.2 & 1.1 & 3.0 & 0.05 & 0.5 & 1.7 \\
Drop size, microns & 314 & 197 & 166 & 459 & 275 & 204 & 788 & 395 & 274 \\
Water temperature, ${ }^{\circ} \mathrm{C}$ & & & & & & & & & \\
\end{tabular}

\section{Results}

Results from conducted experimental research show that used nozzles, sprayed water flowrate and temperature have a strong effect on the fog unit's performance. Flue gas temperature after provided treatment technology depending on nozzles, sprayed water flowrate and temperature is presented in Fig. 1. Fog unit was tested with three nozzle types, three water flows and three inlet water temperatures. Flue gas temperature after the boiler or before the fog unit at all tests was constant $-121^{\circ} \mathrm{C}$. The lowest flue gas temperature after 
the fog unit was achieved using nozzle MPL1.12 M, water flow $250 \mathrm{l} / \mathrm{h}$ and inlet water temperature $20^{\circ} \mathrm{C}$.

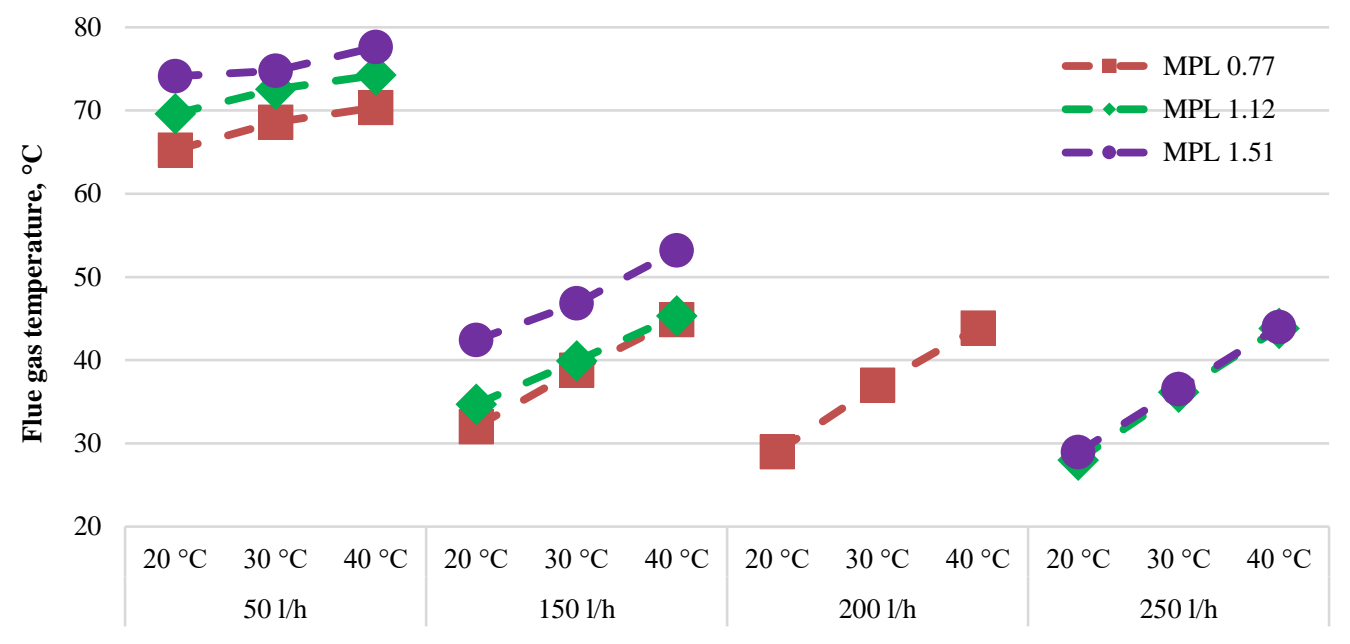

Water flowrate, $\mathrm{l} / \mathrm{h}$ and temperature, ${ }^{\circ} \mathrm{C}$

Fig. 1. Effects of nozzle size, sprayed water flowrate and temperature on flue gas temperature after the fog unit.

It is observed, that at similar water flowrate and temperature the flue gas temperature strongly varies depending on the nozzle used. The reason is difference in sprayed water drop size, which varies from 199 to $314 \mu \mathrm{m}$ for MPL0.77 M, from 204 to $459 \mu \mathrm{m}$ for MPL1.12 M and from 274 to $788 \mu \mathrm{m}$ for MPL1.51 M. The biggest effect of the nozzle was determined at low flowrate $-50 \mathrm{l} / \mathrm{h}$, where, depending on the type of nozzle, flue gas temperature varies at a range from 6.1 to $8.9^{\circ} \mathrm{C}$ at similar temperature. The main reason is the higher difference between sprayed water drop sizes. At high flowrate $(250 \mathrm{l} / \mathrm{h})$ the difference between sprayed water drop sizes is lower $(204 \mu \mathrm{m}$ for MPL1.12 M and $274 \mu \mathrm{m}$ for MPL1.51 M), therefore difference of flue gas temperature after the fog unit is low. The lowest temperature decrease of flue gas was achieved using nozzle MPL1.51 M. It shows that using small drop sizes leads to deeper flue gas cooling.

Three water flowrates were used during the tests $-50 \mathrm{l} / \mathrm{h}, 150 \mathrm{l} / \mathrm{h}$ and $250 \mathrm{l} / \mathrm{h}$. However, it was not possible to achieve a flowrate of $250 \mathrm{l} / \mathrm{h}$ for nozzle MPL0.77 M, since the nozzle diameter is too small and water pressure of around 5.5 bar must be provided at the circulation system. Therefore, flowrates of $50 \mathrm{l} / \mathrm{h}, 150 \mathrm{l} / \mathrm{h}$ and $200 \mathrm{l} / \mathrm{h}$ were used for nozzle MPL0.77 M. Results show that, by increasing water flow from $50 \mathrm{l} / \mathrm{h}$ to $250 \mathrm{l} / \mathrm{h}$, it is possible to decrease flue gas temperature two times from $74.1{ }^{\circ} \mathrm{C}$ to $28.9{ }^{\circ} \mathrm{C}$ (using nozzle MPL1.51 M). Also it was found, that, with increasing sprayed water temperature, the effect of flowrate goes down.

Also sprayed water temperature has strong impact on possibility to decrease flue gas temperature. The effect of water temperature goes up with increase in sprayed water amount. Flue gas temperature decrease of $15.0^{\circ} \mathrm{C}$ (from $44.0^{\circ} \mathrm{C}$ to $28.9{ }^{\circ} \mathrm{C}$ ) can be achieved using nozzle MPL1.51 M, if inlet water temperature will go down from $40{ }^{\circ} \mathrm{C}$ to $20^{\circ} \mathrm{C}$. At the same time, decrease of only $3.5^{\circ} \mathrm{C}$ (from $77.6{ }^{\circ} \mathrm{C}$ to $74.1{ }^{\circ} \mathrm{C}$ ) in flue gas temperature can be achieved by reducing inlet water temperature from $40{ }^{\circ} \mathrm{C}$ to $20^{\circ} \mathrm{C}$ using the same nozzle.

Flue gas moisture content increases if water is sprayed inside. Fig. 2 shows all three parameters: nozzle type, sprayed water flowrate and temperature effects on the absolute 
moisture content of flue gas. Absolute moisture content of flue gas after the boiler and before the fog unit is $26.1 \mathrm{~g} / \mathrm{kg}$ in all tests. The maximal absolute moisture content of flue gas after the fog unit was $59.1 \mathrm{~g} / \mathrm{kg}$ using nozzle MPL1.21 M, injected water flowrate $150 \mathrm{l} / \mathrm{h}$ and temperature $40{ }^{\circ} \mathrm{C}$. Mostly, in all tests, the absolute moisture content of flue gas after the fog unit goes up, however in several tests the reduction of moisture content was achieved. The minimal absolute moisture content $21.1 \mathrm{~g} / \mathrm{kg}$ was achieved using nozzle MPL1.12 M, injected water flowrate $250 \mathrm{l} / \mathrm{h}$ and temperature $20^{\circ} \mathrm{C}$. It means that water vapour condensation in the flue gas can be achieved in the fog unit.

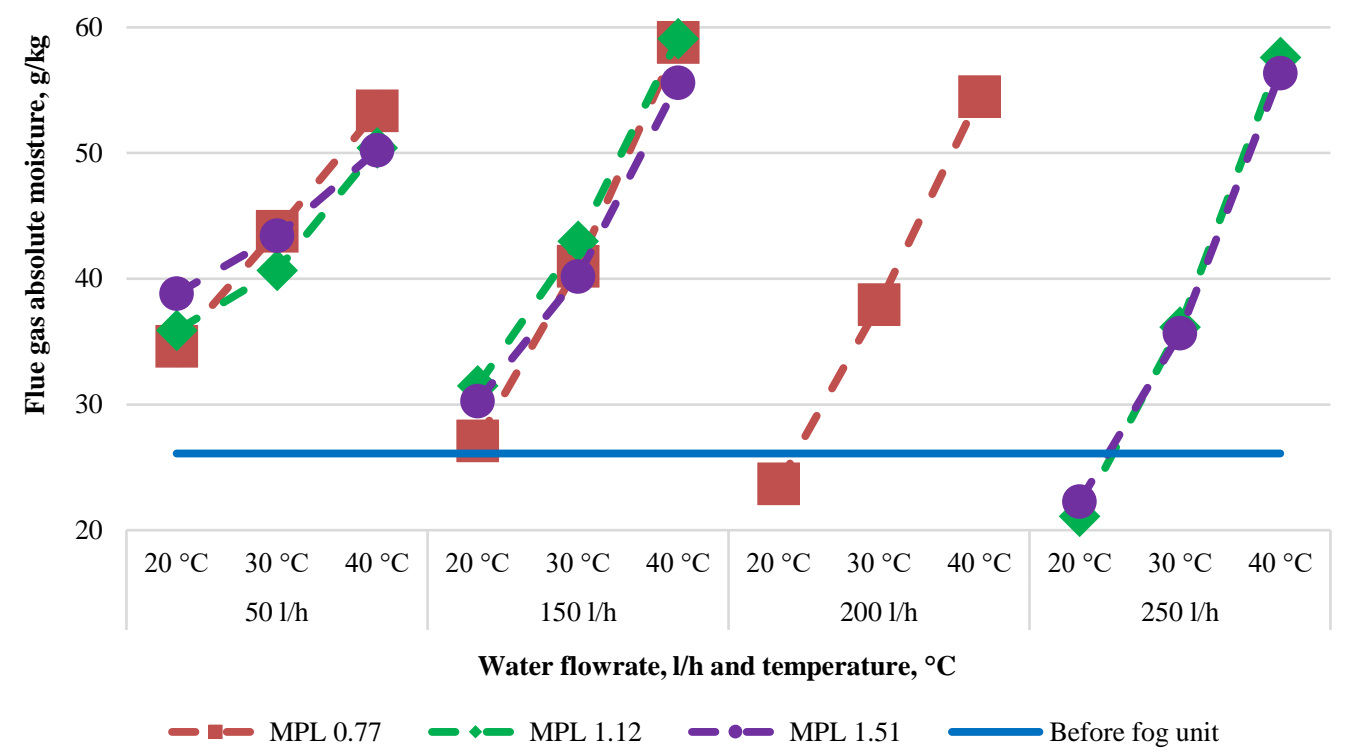

Fig. 2. Effects of nozzle size, sprayed water amount and temperature on absolute moisture content after the fog unit.

Effects of nozzle on the absolute moisture content of flue gas is not as strong as it was found for flue gas temperature. The difference of absolute moisture content of flue gas between used nozzles varies by just $1-3 \mathrm{~g} / \mathrm{kg}$ at high water flowrate. However absolute moisture content of flue gas between used nozzles can vary by $10 \mathrm{~g} / \mathrm{kg}$ at low water flowrate $50 \mathrm{l} / \mathrm{h}$.

The effect of sprayed water flowrate shows a different effect on absolute moisture content of flue gas. The absolute moisture content of flue gas is reduced with increase of water flowrate if sprayed water temperature is between $20^{\circ} \mathrm{C}$ and $30^{\circ} \mathrm{C}$. To the contrary, the absolute moisture content of flue gas can increase if water with temperature $40{ }^{\circ} \mathrm{C}$ is sprayed.

It was found that the sprayed water temperature had a strong effect on absolute moisture content of flue gas. Absolute moisture content can go up by $36.5 \mathrm{~g} / \mathrm{kg}$, from $21.1 \mathrm{~g} / \mathrm{kg}$ to $57.6 \mathrm{~g} / \mathrm{kg}$, using the same nozzle and sprayed water flowrate, only by increase of water temperature from $20{ }^{\circ} \mathrm{C}$ to $40{ }^{\circ} \mathrm{C}$. The effect of inlet water temperature goes down if a lower amount of water is sprayed into the fog unit.

Deeper flue gas cooling is possible if a higher amount of heat can be taken from flue gas by sprayed water. The capacity of the provided technology presents the amount of heat taken from flue gas by water. The effect of used nozzles, sprayed water flowrate and temperature 
on fog unit's capacity is displayed in Fig. 3. Practically similar capacity of the fog unit of 2.6 $\mathrm{kW}$ was achieved using nozzles MPL1.12 M and MPL1.51 M at sprayed water flowrate of $250 \mathrm{l} / \mathrm{h}$ and temperature $20{ }^{\circ} \mathrm{C}$. The lowest flue gas temperature after the fog unit $28-28.9{ }^{\circ} \mathrm{C}$ was achieved exactly at this fog unit operation condition. It is important to note that absolute moisture content of flue gas was lowest $21.1-22.1 \mathrm{~g} / \mathrm{kg}$. However, the effect of used nozzle becomes significant at lower sprayed water capacities - $50 \mathrm{l} / \mathrm{h}$ and $150 \mathrm{l} / \mathrm{h}$. Condenser's capacity can be increased from $0.75 \mathrm{~kW}$ to $1.13 \mathrm{~kW}$ (sprayed water flowrate $50 \mathrm{l} / \mathrm{h}$ and temperature $20^{\circ} \mathrm{C}$ ) if nozzle MPL1.51 M is changed to MPL1.12 M. It means that with smaller sprayed water drops, it is possible to increase the fog unit's capacity.

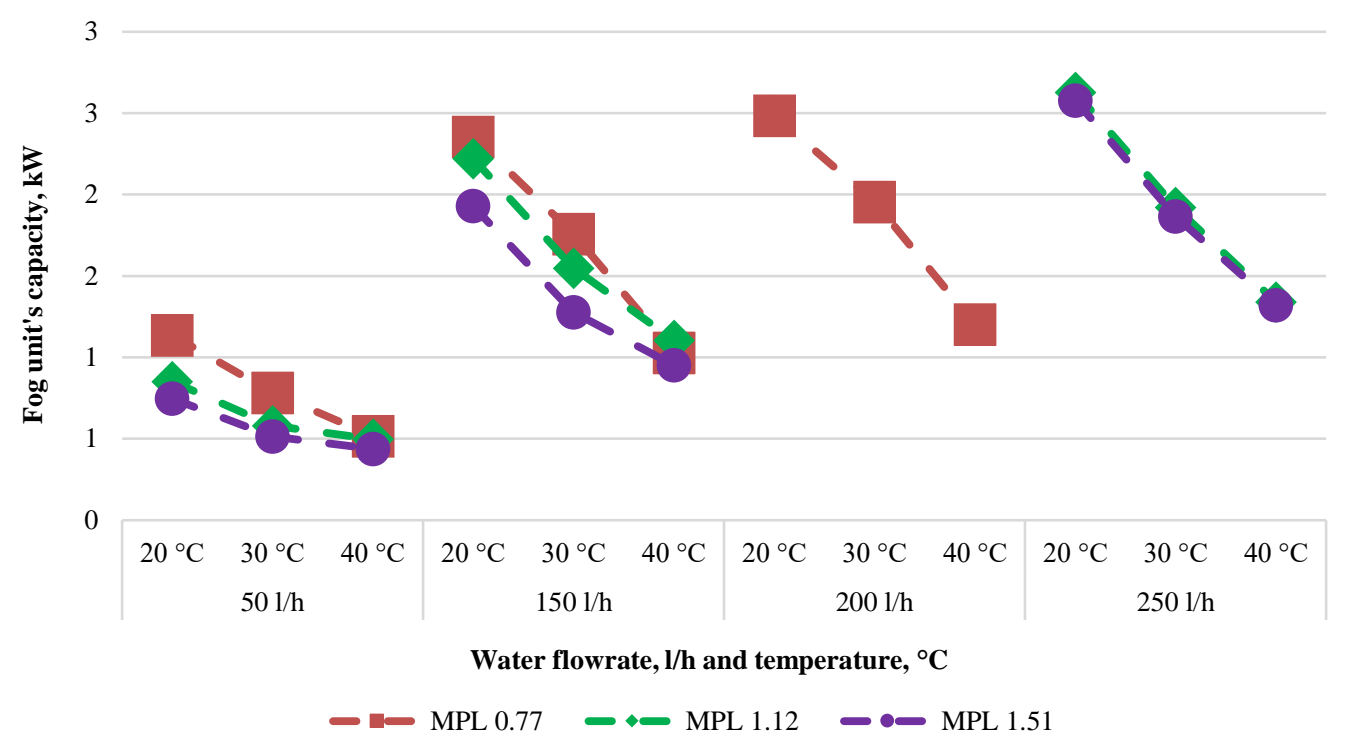

Fig. 3. Effects of nozzle size, sprayed water amount and temperature on condenser's capacity after the fog unit.

Growth of sprayed water flowrate promotes decrease of flue gas temperature and increase of the fog unit's capacity. It is possible to increase the promoted technology's capacity from $1.13 \mathrm{~kW}$ to $2.49 \mathrm{~kW}$ for nozzle MPL0.77 M by increasing sprayed water amount from $50 \mathrm{l} / \mathrm{h}$ to $200 \mathrm{l} / \mathrm{h}$ (using inlet water temperature $20^{\circ} \mathrm{C}$ ). Similarly, for nozzles MPL1.12 M and MPL1.51 M, it is possible to increase fog unit's capacity from $0.85 \mathrm{~kW}$ to $2.63 \mathrm{~kW}$ for nozzle MPL1.12 M and from $0.75 \mathrm{~kW}$ to $2.58 \mathrm{~kW}$ for nozzle MPL1.51 M by increasing sprayed water amount from $50 \mathrm{l} / \mathrm{h}$ to $250 \mathrm{l} / \mathrm{h}$ and using inlet water temperature $20{ }^{\circ} \mathrm{C}$.

The increase of sprayed water temperature promotes flue gas temperature increase, therefore reducing fog unit's capacity. At low sprayed water flowrate $50 \mathrm{l} / \mathrm{h}$, the growth of inlet water temperature from $20^{\circ} \mathrm{C}$ to $40{ }^{\circ} \mathrm{C}$, adds to condenser's capacity reduction by $0.3-0.6 \mathrm{~kW}$. At the same time, the growth of inlet water temperature from $20^{\circ} \mathrm{C}$ to $40{ }^{\circ} \mathrm{C}$ promotes the condenser's capacity reduction by $1.3 \mathrm{~kW}$, if sprayed water flowrate is $250 \mathrm{l} / \mathrm{h}$.

The energy efficiency of promoted technology is called relationship between heat amount taken from flue gas by sprayed water and heat amount injected in the boiler at the same time period. Fog unit's efficiency can be represented using Eq. (1): 


$$
\eta_{\text {fog unit }}=\frac{Q_{\text {fog unit }}}{Q_{\text {fuel }}} \cdot 100,
$$

where

$\eta_{\text {fog unit }} \quad$ Fog unit's efficiency, $\%$;

$Q_{\text {fog unit }} \quad$ Recovered heat from flue gas by the fog unit, kWh;

$Q_{\text {fuel }} \quad$ The amount of fuel energy entered in the boiler, $\mathrm{kWh}$.

Fog unit's efficiency depending on used nozzle and sprayed water flowrate is presented in Table 2. The variation between efficiency values at similar nozzles and sprayed water flowrate represent effect of inlet water temperature. A higher amount of heat can be removed from flue gas with sprayed water temperature $20{ }^{\circ} \mathrm{C}$, as presented before. Therefore, the biggest achieved energy efficiency of the fog unit was also achieved at sprayed water temperature $20^{\circ} \mathrm{C}$. Results show that maximal technology's energy efficiency is $11.4 \%$. This efficiency can be achieved with nozzle MPL1.12 M and water flowrate $250 \mathrm{l} / \mathrm{h}$. The decrease of injected water flowrate promotes decrease of fog unit's energy efficiency. The nozzle MPL0.77 $\mathrm{M}$ is more effective at flowrates 50-150 1/h, but nozzle MPL1.12 $\mathrm{M}$ at highest flowrate $250 \mathrm{l} / \mathrm{h}$.

TABLE 2. FOG UNIT ENERGY EFFICIENCY DEPENDING FROM NOZZLE TYPE AND WATER FLOWRATE

\begin{tabular}{|c|c|c|c|}
\hline \multirow{2}{*}{ Flowrate/Nozzle type } & MPL0.77 M & MPL1.12 M & MPL1.51 M \\
\hline & \multicolumn{3}{|c|}{ Fog unit energy efficiency, $\%$} \\
\hline $50 \mathrm{l} / \mathrm{h}$ & $2.3-5.0$ & $2.2-3.7$ & $1.9-3.2$ \\
\hline $150 \mathrm{l} / \mathrm{h}$ & $4.5-10.4$ & $4.8-9.6$ & $4.1-8.4$ \\
\hline $2501 / h$ & $5.3-10.9^{*}$ & $5.8-11.4$ & $5.7-11.2$ \\
\hline
\end{tabular}

${ }^{*}$ For nozzle MPL0.77 M at water flow 200 1/h.

Even though this study focuses on the possibility to recover heat from flue gas by provided technology, the main task of the fog unit is reduction of particulate matter concentration in flue gas. It was measured that particulate matter concentration after the boiler or before the fog unit is $36.2 \mathrm{mg} / \mathrm{Nm}^{3}$. The achieved particulate matter reduction depending on type of nozzle and sprayed water flowrate is presented in Table 3. Results show that it is possible to obtain particulate matter reduction from $70 \%$ to $77.3 \%$ with each nozzle type, if water flowrate is $150 \mathrm{l} / \mathrm{h}$ and higher. A more detailed study about particulate matter reduction with the fog unit technology can be found in another paper done by Priedniece et al. [31]. 


\section{TABLE 3. RESULTS OF PM REDUCTION EFFICIENCY DEPENDING ON NOZZLE TYPE AND WATER FLOWRATE}

\begin{tabular}{llll}
\hline \multirow{2}{*}{ Flowrate/Nozzle type } & MPL0.77 M & \multicolumn{1}{c}{ MPL1.12 M } & MPL1.51 M \\
& Fog unit PM reduction efficiency, \% & \\
\hline $50 \mathrm{l} / \mathrm{h}$ & $28.6-35.5$ & $33.6-47.0$ & $37.0-73.4$ \\
$150 \mathrm{l} / \mathrm{h}$ & $57.2-71.2$ & $33.2-77.3$ & $39.1-74.0$ \\
$250 \mathrm{l} / \mathrm{h}$ & $37.1-69.8^{*}$ & $69.2-70.9$ & $41.7-77.2$ \\
\hline
\end{tabular}

Water spraying in the fog unit was organized by using circulation water pump. Each tested nozzle has specific inlet diameter which affects pressure losses at the fog unit's hydraulic system. Therefore, electrical consumption of the pump is different for each nozzle. MPL0.77 M provides water spraying with smallest water drop sizes, in turn providing the need for higher electricity consumption of the pump. The electricity consumption of the pump goes up with increase of water flowrate, since water pressure in the hydraulic system grows. Electricity consumption of the pump needs to be higher than $2 \mathrm{~kW}$ to provide water spraying with nozzle MPL1.12 M and water flowrate $250 \mathrm{l} / \mathrm{h}$. However, electricity consumption of the pump was only $781 \mathrm{~kW}$ when nozzle MPL1.51 M was used and water flowrate was $250 \mathrm{l} / \mathrm{h}$. Fog unit's capacity is practically similar at water flowrate $250 \mathrm{l} / \mathrm{h}$ using nozzle MPL1.12 M and MPL1.51 M. Therefore, it is important to take into account the pump's electricity consumption, to also find optimal parameters for the fog unit's operation.

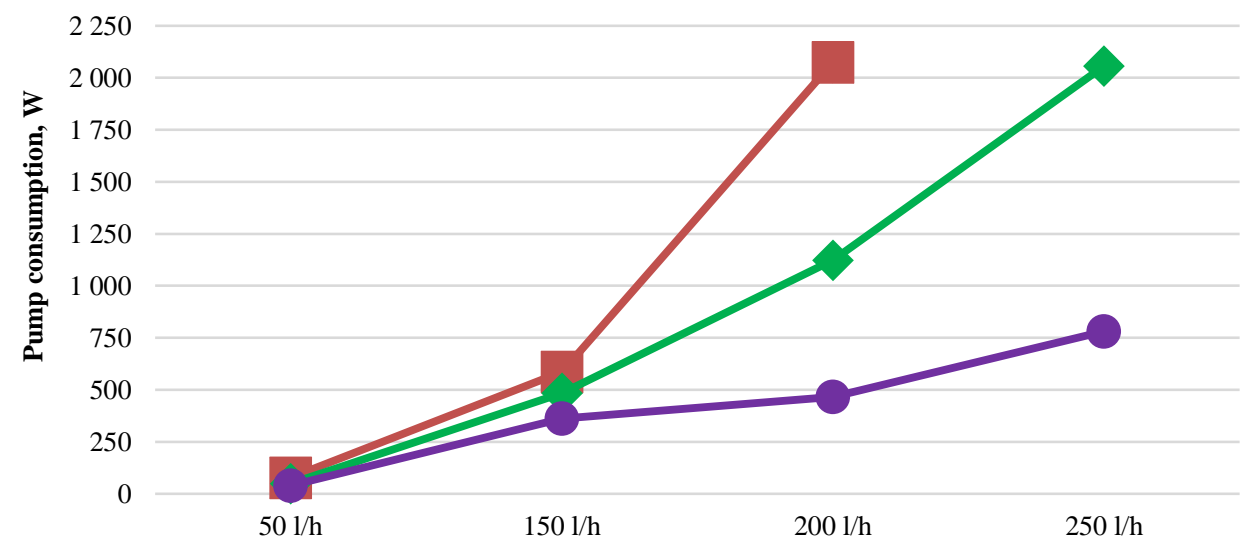

Water flowrate, $\mathrm{l} / \mathrm{h}$ and temperature, ${ }^{\circ} \mathrm{C}$

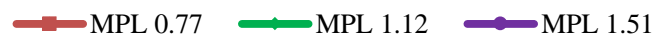

Fig. 4. Effects of nozzle size, sprayed water amount and temperature on pump's electricity consumption.

Data analysis was performed using STATGRAPHICS Centurion 16.1.17 software. Results show that there is a strong correlation between the fog unit's capacity and its operation parameters - sprayed water flowrate, temperature and water drop sizes. The $\mathrm{R}^{2}$ value of regression model is 0.91 , the $P$-value is less than 0.05 , describing significant relationship between variables at $95.0 \%$ confidence level. The standard error of residuals is 0.21 , but mean absolute error $=0.17$. The equation for the model is Eq. (2): 


$$
\mathrm{q}_{\text {fog unit }}=2.2285+0.0058 \cdot m_{\text {water }}-0.0468 \cdot T_{\text {water }}-0.0007 \cdot D_{\text {drop }} \text {, }
$$

where

qfog unit Fog unit's capacity, kW;

$m_{\text {water }} \quad$ Sprayed water flowrate, $1 / \mathrm{h}$;

$T_{\text {water }} \quad$ Sprayed water temperature, ${ }^{\circ} \mathrm{C}$;

$D_{\text {drop }} \quad$ Sprayed water drop size, microns.

The difference between measured and calculated capacities of the fog unit using achieved multiple regression equation is displayed in Fig. 5. The Figure shows, that the biggest difference between measured and calculated variables can be found at low capacities below $0.5 \mathrm{~kW}$. It means that there can be some additional factors affecting the fog unit's capacity.

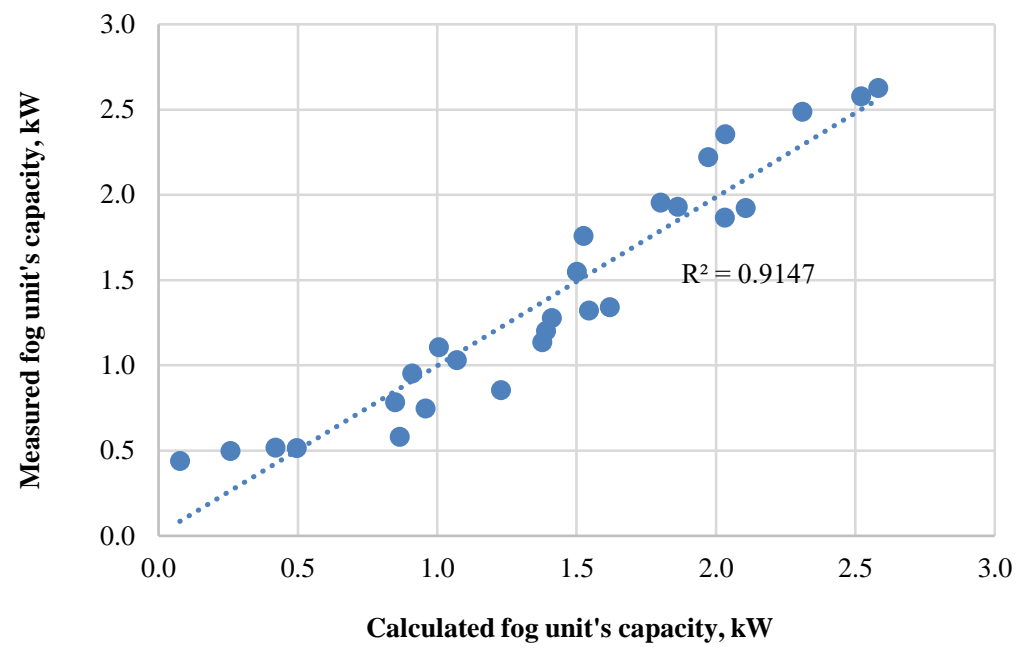

Fig. 5. Comparison of measured and calculated capacities of the fog unit.

\section{Conclusions}

The experimental research focusing on innovative technology of flue gas treatment was done. The operation principle of treatment technology is based on water spraying into flue gas. The size of injected water drops is small and varies from 165 to 788 microns depending on the type of nozzle used. The fog effect inside the treatment technology, which is called a fog unit, is created as a result. The technology is designed for small capacity boilers installed at households.

This study is focused on the possibility to recover heat from flue gases created by a pellet boiler with the capacity of $20 \mathrm{~kW}$ using the provided technology. The effects of various sprayed water flowrates, inlet water temperature and types of nozzles on the fog unit's performance were investigated. It was determined that lower flue gas temperature $28.0{ }^{\circ} \mathrm{C}$ after the fog unit $\left(121^{\circ} \mathrm{C}\right.$ before the fog unit) can be achieved using nozzle MPL1.12 $\mathrm{M}$ and sprayed water flowrate $250 \mathrm{l} / \mathrm{h}$ with inlet temperature $20^{\circ} \mathrm{C}$. Also maximal fog unit's capacity of $2.6 \mathrm{~kW}$ was achieved using the same operation conditions. The decrease of water flowrate from $250 \mathrm{l} / \mathrm{h}$ to $50 \mathrm{l} / \mathrm{h}$ promotes growth of flue gas temperature and decrease of fog unit's 
capacity. Also, the increase of injected water temperature from $20{ }^{\circ} \mathrm{C}$ to $40{ }^{\circ} \mathrm{C}$ has negative effect on flue gas cooling.

Water spraying promotes increase of absolute moisture content in the flue gas. Two times higher absolute moisture content can be achieved $(26 \mathrm{~g} / \mathrm{kg}$ before the fog unit and $50-56 \mathrm{~g} / \mathrm{kg}$ ) if sprayed water temperature is $40{ }^{\circ} \mathrm{C}$. However, it is also possible to get reduction of moisture content using high sprayed water flowrates with inlet water temperature $20{ }^{\circ} \mathrm{C}$, which means water vapour condensation occurs in the fog unit.

Water spraying in the fog unit was provided by using a circulation water pump. To define the most energy efficient operation regimes of the fog unit operation, the electrical consumption of the circulation water pump must be taken into account. The electrical consumption is lower if nozzle MPL1.51 M is used.

Finally, the data analysis of the experimental results was conducted and multivariable regression model was found, which presents the capacity of the fog unit as a function of sprayed water flowrate, temperature and water drop sizes.

\section{Acknowledgement}

The work has been supported by European Regional Development Fund project "Individual Heating with Integrated Fog Unit System (IFUS)" 1.1.1.1/16/A/015.

\section{References}

[1] Geng L., et al. The end effect in air pollution: The role of perceived difference. Journal of Environmental Management 2019:232:413-420. doi:10.1016/j.jenvman.2018.11.056

[2] Ziyarati T. M., et al. Greenhouse gas emission estimation of flaring in a gas processing plant: Technique development. Process Safety and Environmental Protection 2019:123:289-298. doi:10.1016/j.psep.2019.01.008

[3] Wu W., Jin Y., Carlsten C. Inflammatory health effects of indoor and outdoor particulate matter. Journal of Allergy and Clinical Immunology 2018:141(3):845. doi:10.1016/j.jaci.2017.12.981

[4] Kim K. H., Kabir E., Kabir S. A review on the human health impact of airborne particulate matter. Environment International 2015:74:136-143. doi:10.1016/j.envint.2014.10.005

[5] CSB. Vides rādītāji Latvijā 2016. gadā. (Environmental indicators in Latvia 2016.) Riga: CSB, 2017:6.

[6] World health organization Media centre. WHO | Ambient (outdoor) air quality and health. WHO, 2016.

[7] Legal Acts of the Republic of Latvia. Regulations regarding Ambient Air Quality [Online]. [Accessed 21.03.2018]. Available: https://likumi.lv/ta/en/en/id/200712

[8] Rīgas pilsētas gaisa piesārņojuma ar cietajām daḷiņām (PM 10) teritoriālo zonu kartes Paskaidrojuma raksts. Riga: Rigas domes MVD, 2014.

[9] CSB. EPM340. Energoresursu patēriņš mājsaimniecībās, ieskaitot patēriṇa lauku saimniecībās un citās ekonomiskās $\begin{array}{lllll}\text { aktivitātēs (TJ). PxWeb. } & \text { [Online]. }\end{array}$ http://data1.csb.gov.lv/pxweb/lv/vide/vide_energetika_energ_pat/EPM340.px/?rxid=a39c3f49-e95e-43e7-b4f0dce111b48ba1 (in Latvian)

[10] Růžičková J., et al. Comparison of organic compounds in char and soot from the combustion of biomass in boilers of various emission classes. Journal of Environmental Management 2018:236:769-783. doi:10.1016/j.jenvman.2019.02.038

[11] Hupa M., Karlström O., Vainio E. Biomass combustion technology development - It is all about chemical details. Proceedings of the Combustion Institute 2017:36(1):113-134. doi:10.1016/j.proci.2016.06.152

[12] Saidur R., et al. A review on biomass as a fuel for boilers. Renewable and Sustainable Energy Reviews 2011:15(5):2262-2289. doi:10.1016/j.rser.2011.02.015

[13] Yongtie C., et al. Modelling of ash deposition in biomass boilers: A review. Energy Procedia 2017:143:623-628. doi:10.1016/j.egypro.2017.12.737

[14] Bešenić T., et al. Numerical modelling of emissions of nitrogen oxides in solid fuel combustion. Journal of Environmental Management 2018:215:177-184. doi:10.1016/j.jenvman.2018.03.014

[15] Wolf C., et al. Environmental effects of shifts in a regional heating mix through variations in the utilization of solid biofuels. Journal of Environmental Management 2016:177:177-191. doi:10.1016/j.jenvman.2016.04.019

[16] Klauser F., et al. Emission characterization of modern wood stoves under real-life oriented operating conditions. Atmospheric Environment 2018:192:257-266. doi:10.1016/j.atmosenv.2018.08.024 
[17] Bajcinovci B., Jerliu F. Achieving energy efficiency in accordance with bioclimatic architecture principles. Environmental and Climate Technologies 2016:18(1):54-63. doi:10.1515/rtuect-2016-0013

[18] Klavins M., Bisters V., Burlakovs J. Small Scale Gasification Application and Perspectives in Circular Economy. Environmental and Climate Technologies 2018:22(1):42-54. doi:10.2478/rtuect-2018-0003

[19] Directive 2009/125/EC of the European Parliament and of the Council of 21 October 2009 establishing a framework for the setting of ecodesign requirements for energy-related products. Official Journal of European Union 2009:L $285 / 10$.

[20] Singh R., Shukla A. A review on methods of flue gas cleaning from combustion of biomass. Renewable and Sustainable Energy Reviews 2014:29:854-864. doi:10.1016/j.rser.2013.09.005

[21] Vigants E., et al. Modelling of Technological Solutions to 4th Generation DH Systems. Environmental and Climate Technologies 2017:20(1):5-23. doi:10.1515/rtuect-2017-0007

[22] Gao D., et al. Moisture and latent heat recovery from flue gas by nonporous organic membranes. Journal of Cleaner Production 2019:225:1065-1078. doi:10.1016/j.jclepro.2019.03.326

[23] Cortina M. Flue gas condenser for biomass boilers, 2006.

[24] Jenkins C. F. Condensers. 2011:2(6).

[25] Barma M. C., et al. A review on boilers energy use, energy savings, and emissions reductions. Renewable and Sustainable Energy Reviews 2017:79:970-983. doi:10.1016/j.rser.2017.05.187

[26] Zhao S., et al. Simultaneous heat and water recovery from flue gas by membrane condensation: Experimental investigation. Applied Thermal Engineering 2017:113:843-850. doi:10.1016/j.applthermaleng.2016.11.101

[27] Wei M., et al. Experimental investigation on vapor-pump equipped gas boiler for flue gas heat recovery. Appied Thermal Engineering 2019:147:371-379. doi:10.1016/j.applthermaleng.2018.07.069

[28] Ramanauskas V., Miliauskas F. The water droplets dynamics and phase transformations in biofuel flue gases flow. International Journal of Heat and Mass Transfer 2019:131:546-557. doi:10.1016/j.ijheatmasstransfer.2018.06.095

[29] Terhan M., Comakli K. Design and economic analysis of a flue gas condenser to recover latent heat from exhaust flue gas. Applied Thermal Engineering 2016:100:1007-1015. doi:10.1016/j.applthermaleng.2015.12.122

[30] Vigants G., et al. Efficiency Diagram for District Heating System with Gas Condensing Unit. Energy Procedia 2015:72:119-126. doi:10.1016/j.egypro.2015.06.017

[31] Priedniece V., et al. Particulate matter emission decrease possibility from household sector using flue gas condenser - fog unit. Analysis and interpretation of results. Environmental and Climate Technologies 2019:23(1):135-151. doi:10.2478/rtuect-2019-0010

[32] Priedniece V., et al. Laboratory research of the flue gas condenser - fog unit. Energy Procedia 2018:147:482-487. doi:10.1016/i.egypro.2018.07.056

[33] Priedniece V., et al. Experimental and analytical study of the flue gas condenser - fog unit. Energy Procedia 2019:158:822-827. doi:10.1016/j.egypro.2019.01.215 